\title{
HASIL BELAJAR PEMOGRAMAN VISUAL I DITINJAU DARI GAYA BELAJAR MAHASISWA
}

\author{
Ridho Dedy Arief Budiman \\ Program Studi Pendidikan Teknologi Informasi dan Komputer, IKIP PGRI Pontianak, Jalan Ampera \\ Nomor 88 Pontianak Kalimantan Barat Indonesia \\ *email: ridho.asytarrazi@gmail.com
}

\section{Received: 21 Maret 2019 Accepted: 1 Juni 2019 Published: 30 Juni 2019}

\begin{abstract}
Abstrak
Penelitian ini bertujuan untuk mengetahui perbedaan hasil belajar pemrograman visual I mahasiswa dengan gaya belajar visual, gaya belajar auditori, dan gaya belajar kinestetik. Jenis penelitian ini adalah ex-post facto dengan desain penelitian kausal komparatif. Populasi penelitian adalah seluruh mahasiswa semester IV yang berjumlah 270 orang dan sampel penelitian sejumlah 159 orang dengan teknik proportional random sampling. Pengumpulan data menggunakan kuesioner dan dokumentasi. Teknik analisis data yang digunakan adalah statistik deskriptif, one way anova, independent t-test. Hasil penelitian ini menunjukkan bahwa tidak terdapat perbedaan hasil belajar pemrograman visual 1 antar mahasiswa dari gaya belajar visual, gaya belajar auditori, dan gaya belajar kinestetik.
\end{abstract}

Kata kunci: gaya belajar visual, gaya belajar auditori, gaya belajar kinestetik, hasil belajar.

\begin{abstract}
This study aims to investigate the differences of the visual I programming learning achievement of students with visual learning style, auditory learning style, and kinesthetic learning style. This was an expost facto study using the causal comparative research design. The study population is all semester IV students with a total of 270 students and the sample consisted of 159 students was established by means of the proportional random sampling technique. The data were collected through questionnaires and documentation. The data analysis technique used was statistics descriptive, one way anova, independent $t$-test. The results of the study show there is no differences visual I programming learning achievement between students with visual learning style, auditory learning style, and kinesthetic learning style.
\end{abstract}

Keywords: visual learning styles, auditory learning styles, kinesthetic learning, learning achievement.

(C) 2019 LPPM IKIP PGRI Pontianak, Indonesia

\section{PENDAHULUAN}

Program Studi Pendidikan Teknologi Informasi dan Komputer IKIP PGRI Pontianak menerapkan kurikulum yang tidak hanya berfokus pada ranah kognitif dan afektif saja, namun juga berfokus pada ranah psikomotorik yang ditunjukkan dengan dimasukkannya mata kuliah yang bersifat praktik. Mata kuliah yang bersifat praktik tersebut diantaranya adalah mata kuliah 
yang terkait dengan pemrograman komputer, dalam penelitian ini adalah mata kuliah pemrogram visual I.

Pembelajaran pemrograman membutuhkan keahlian seperti abstraksi, generalisasi, mentransfer, dan berpikir kritis yang tidak gampang dibentuk (Marcelino, 2004). Suatu program yang baik harus dibuat desain terlebih dahulu. Kemudian Marcelino (2004) menjelaskan bahwa langkah-langkah untuk menyusun sebuah program yang dapat dilakukan oleh mahasiswa adalah (1) menganalisa input, proses, dan output; (2) menggambar flowchart; (3) mengecek kesesuaian flowchart dengan masalah yang dipecahkan (desk-check); (4) mengubah flowchart menjadi kode-kode program; (5) melacak kesalahan sintaks; membandingkan hasil running program dengan hasil desk-check untuk menemukan kesalahan logika; dan (6) mendokumentasikan hasil. Materi pembelajaran tentang pemrograman visual 1 saling berkaitan dan merupakan kelanjutan dari materi sebelumnya. Mahasiswa yang merasa sulit dalam menuntaskan soal atau latihan pada materi pembelajaran diawal, maka akan menjadi lebih kesulitan dalam materi pembelajaran selanjutnya. Materi pembelajaran tentang pemrograman visual 1 menuntut keterampilan mahasiswa untuk dapat menyelesaikan berbagai permasalahan. Salah satu permasalahan yang harus diselesaikan yaitu membuat suatu program aplikasi bisnis atau program aplikasi pembelajaran dengan menggabungkan pengetahuan dan keterampilan (skill) yang dimiliki. Selain itu, pembelajaran tentang pemrograman visual 1 mengajarkan mahasiswa tentang dasardasar algoritma dan kaitannya dengan teknik pemrograman yang menekankan pada aspek, konsep, dan implementasinya pada bahasa pemrograman, serta cara menganalisis masalah yang kemudian merancang pemecahan masalah dengan menggunakan algoritma dan pemrograman terstruktur/prosedural. Mahasiswa yang memiliki kesadaran rendah belajar pemrograman visual 1, maka akan semakin malas dalam mengerjakan karena tidak dapat berpikir menggunakanlogika untuk mencari solusi permasalahan. Sehingga, hasil belajar yang diperoleh mahasiswa juga akan rendah dan kurang memuaskan.

Hasil belajar menurut Purwanto (2007) merupakan perolehan dari proses belajar siswa sesuai dengan tujuan pembelajaran (ends are being attained). Kemudian Winkel (2004) menyatakan hasil belajar merupakan perubahan akibat belajar yang terjadi pada individu meliputi kemampuan kognitif, sensorik-motorik, dan dinamik-afektif. Pada prinsipnya, hasil belajar dapat dilihat dari tiga aspek, yaitu aspek kognitif, afektif, dan psikomotorik. Aspek kognitif meliputi perubahan kemampuan berpikir dan keterampilan selama proses belajar. Aspek 
afektif meliputi perubahan sikap, minat, dan nilai-nilai yang terkait dengan perasaan siswa. Sedangkan, aspek psikomotorik meliputi hasil yang diperoleh oleh siswa selama proses belajar.

Hasil belajar dapat dipengaruhi oleh beberapa faktor, yaitu faktor dari dalam diri siswa maupun dari lingkungan. Hasil belajar yang dipengaruhi oleh faktor dalam diri siswa dapat berupa gaya belajar siswa. Berdasarkan pada hasil belajar pemrograman visual 1 mahasiswa yang dilihat dari nilai tes akhir yang murni, masih banyak terdapat mahasiswa yang belum mencapai nilai minimum. Gaya belajar diyakini mampu memberikan pengaruh terhadap motivasi belajar mahasiswa yang pada akhirnya juga akan mempengaruhi hasil belajar. Gaya belajar adalah cara yang digunakan mahasiswa dalamprosespembelajaran. Menurut Law dan Glover (2000) mengidentifikasi bahwa keberhasilan dari sebuah proses pembelajaran sangat bergantung dari strategi belajar dan cara mengajar yang digunakan untuk memaksimalkan kemampuan mahasiswa. Selain itu, dosen juga perlu memperhatikan strategi pembelajaran yang tepat yang sesuai dengan gaya belajar mahasiswa. Gaya belajar memiliki banyak manfaat atau keuntungan dalam pembelajaran jika dosen memahami kondisi mahasiswa dan mahasiswa memahami kemampuan dan gaya belajar yang dimiliki. Gilakjani (2012) menyatakan terdapat 3 kelompok gaya belajar, yaitu gaya belajar tipe visual, auditorial, dan kinestetik. Tiap gaya belajar memiliki pengertian dan ciri-ciri yang berbeda. Ciri-ciri dari tiap gaya belajar, mempengaruhi cara siswa menyerap informasi pembelajaran.

Gaya belajar dalam pembelajaran pemograman komputer, perlu diketahui oleh dosen agar dapat mengarahkan mahasiswa pada pembelajaran yang efektif. Mahasiswa memiliki kebutuhan belajar sendiri, belajar dengan cara berbeda, serta memproses informasi dengan cara yang berbeda. Pembelajaran pemograman computer memerlukan tingkat pemahaman yang sangat besar oleh mahasiswa. Oleh karena itu jika gaya mengajar dosen tidak memperhatikan kebutuhan khusus mahasiswa, maka belajar tidak akan terjadi. Ketika dosen mengajar sesuai dengan gaya belajar mahasiswa, dosen sama dengan memberitahu pada mahasiswa bahwa dosen mengetahui mahasiswa adalah individu yang mungkin belajar dengan cara berbeda dengan mahasiswa lain.

Dari penjelasan tersebut dapat diketahui bahwa gaya belajar adalah cara yang digunakan mahasiswa dalam menerima informasi, melakukan pekerjaan, dan memahami penjelasan pembelajaran. Secara realitas bahwa hal ini dikarenakan mahasiswa belajar dengan gaya belajar yang disukainya tentu cenderung akan memberikan hasil yang baik. Fenomena yang terjadi di 
lapangan bahwa sebagian mahasiswa belum mengerti dan memahami gaya belajar yang dimiliki. Mahasiswa hanya mengikuti kondisi yang ada pada saat mereka belajar.

Berdasarkan penjelasan mengenai mata kuliah Pemograman Komputer dan hasil belajar, maka peneliti ingin mengetahui sejauh mana perbedaan hasil belajar Pemrograman Visual I mahasiswa Program Studi Pendidikan Teknologi Informasi dan Komputer IKIP PGRI Pontianak ditinjau dari gaya belajar. Sebelum penelitian dilakukan, diadakan observasi untuk melihat ketersediaan penelitian yang sama pada program studi tersebut. Hasil observasi diketahui bahwa penelitian di Program Studi Pendidikan Teknologi Informasi dan Komputer IKIP PGRI Pontianak yang membahas tentang perbedaan hasil belajar pemrograman visual 1 ditinjau dari gaya belajar belum pernah dilakukan. Tujuan dari penelitian ini untuk mengetahui perbedaan hasil belajar pemrograman visual 1 mahasiswa Program Studi Pendidikan Teknologi Informasi dan Komputer IKIP PGRI Pontianak ditinjau dari gaya belajar.

\section{METODE}

Penelitian ini tergolong dalam penelitian ex-post facto. Desain penelitian yang digunakan adalah kausal komparatif. Penelitian dilakukan di IKIP PGRI Pontianak, pada Program Studi Pendidikan Teknologi Informasi dan Komputer. Populasi penelitian adalah seluruh mahasiswa semester IV yang mengambil mata kuliah Pemrograman Visual I yang berjumlah 270 mahasiswa. Penentuan sampel dalam penelitian ini dilakukan dengan menggunakan teknik proportional random sampling sesuai dengan jumlah populasi mahasiswa semester IV. Penentuan jumlah sampel menggunakan bantuan tabel sampel dari Isaac dan Michael. Jumlah sampel dari populasi 270 orang dengan menggunakan tabel sampel dari Isaac dan Michael tersebut dengan taraf kesalahan 5\% adalah sebanyak 159 orang atau 58,90\%. Teknik pengumpulan data dalam penelitian ini menggunakan kuesioner dan dokumentasi. Kuesioner digunakan untuk memperoleh data tentang variabel bebas, yaitu motivasi, lingkungan belajar, dan gaya belajar. Dokumentasi dilakukan untuk memperoleh data tentang variabel terikat, yaitu hasil belajar mahasiswa. Instrumen yang digunakan berupa angket yang berisi pernyataanpernyataan yang menyangkut motivasi belajar lingkungan belajar, dan gaya belajar. Angket yang dibuat berbentuk skala likert terdiri dari pernyataan positif dan negatif dengan rentang skor 1-4. Teknik analisis data yang digunakan pada penelitian ini adalah analisis deskriptif dan analisis statistik parametrik. Pada analisis deskriptif menggambarkan data dalam bentuk frekuensi 
masing-masing variabel. Pada analisis statistik parametrik menggunakan uji hipotesis yang harus memenuhi syarat normalitas dan homogenitas. Pada variabel gaya belajar uji hipotesis menggunakan One Way Anova dengan bantuan SPSS 20.0 for Windows.

\section{HASIL DAN PEMBAHASAN}

Penelitian dianalisis secara deskriptif untuk mengetahui gambaran dari variabel penelitian dan analisis inferensial untuk mengetahui besarnya pengaruh dari tiap-tiap variabel penelitian. Dari hasil belajar pemrograman visual 1 diperoleh nilai rata-rata (mean) sebesar 54,86; nilai tengah (median) sebesar 55,00; nilai modus (mode) sebesar 50, menunjukkan bahwa nilai ini yang paling banyak frekuensi kemunculannya; nilai variansi sebesar 32,626; nilai range sebesar 33, range menunjukkan selisih antara nilai tertinggi dengan nilai terendah; nilai terendah sebesar 40; nilai tertinggi sebesar 73; dan nilai untuk semua data (sum) sebesar 8723.

Selain itu hasil analisis menunjukkan bahwa hasil belajar pemrograman visual 1 mahasiswa untuk kategori sangat baik sebanyak 41 orang atau 25,79\%; kategori baik sebanyak 104 orang atau 65,41\%; kategori kurang sebanyak 14 orang atau 8,81\%; dan kategori sangat kurang sebanyak 0 orang atau 0\%. Dengan demikian, dapat disimpulkan bahwa hasil belajar pemrograman visual 1 mahasiswa memiliki kecenderungan yang baik dengan persentase sebesar 65,41\%. Hasil belajar secara keseluruhan dapat dilihat pada Gambar 1.

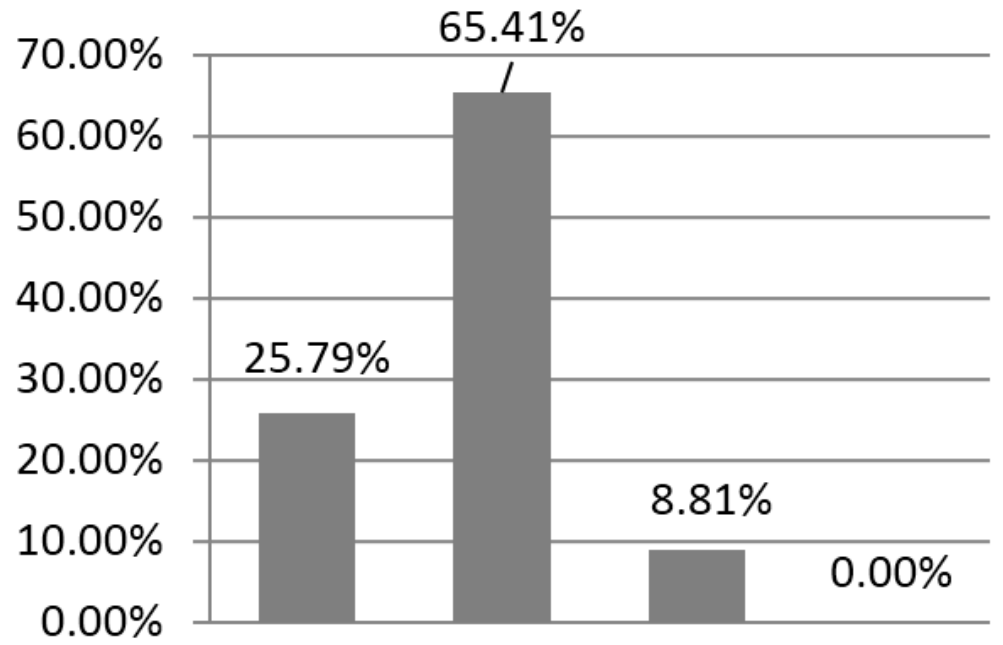

Gambar 1. Hasil Belajar Mahasiswa

Berdasarkan hasil analisis gaya belajar mahasiswa Program Studi Pendidikan Teknologi Informasi dan Komputer IKIP PGRI Pontianak pada mata kuliah Pemrograman visual 1 , 
diketahui bahwa mahasiswa yang bergaya belajar visual berjumlah 33 orang dengan rata-rata (mean) sebesar 52,61; simpangan baku (standard deviation) sebesar 7,599; dan varian (variance) sebesar 57,746. Untuk mahasiswa yang bergaya belajar auditori berjumlah 53 orang dengan ratarata (mean) sebesar 52,68; simpangan baku (standard deviation) sebesar 7,815 dan varian (variance) sebesar 61,068. Sedangkan mahasiswa yang bergaya belajar kinestetik berjumlah 73 orang dengan rata-rata (mean) sebesar 54,71; simpangan baku (standard deviation) sebesar 9,633 dan varian (variance) sebesar 92,791.

Selain itu diketahui bahwa dari 159 mahasiswa semester IV Program Studi Pendidikan Teknologi Informasi dan Komputer IKIP PGRI Pontianak pada mata kuliah pemrograman visual 1, memiliki gaya belajar visual dengan persentase $20,75 \%$, gaya belajar auditori dengan persentase 33,33\%, dan gaya belajar kinestetik dengan persentase 45,92\%. Disimpulkan bahwa gaya belajar tertinggi pada pemrograman visual 1 dimiliki mahasiswa pada gaya belajar kinestetik dan auditori serta gaya belajar terendah pada gaya belajar visual.

Rerata skor kecenderungan dari masing-masing jenis gaya belajar dari yang paling tinggi adalah gaya belajar kinestetik 54,71; gaya belajar auditori 52,68 dan gaya belajar visual 52,61. Dengan demikian dalam penelitian ini gaya belajar kinestetik memberikan kontribusi terbesar terhadap hasil belajar Pemrograman visual 1 mahas iswa selanjutnya adalah gaya belajar auditori dan yang paling rendah kontribusinya adalah gaya belajar visual. Persentase klasifikasi gaya belajar mahasiswa secara keseluruhan dapat dilihat pada Gambar 2.

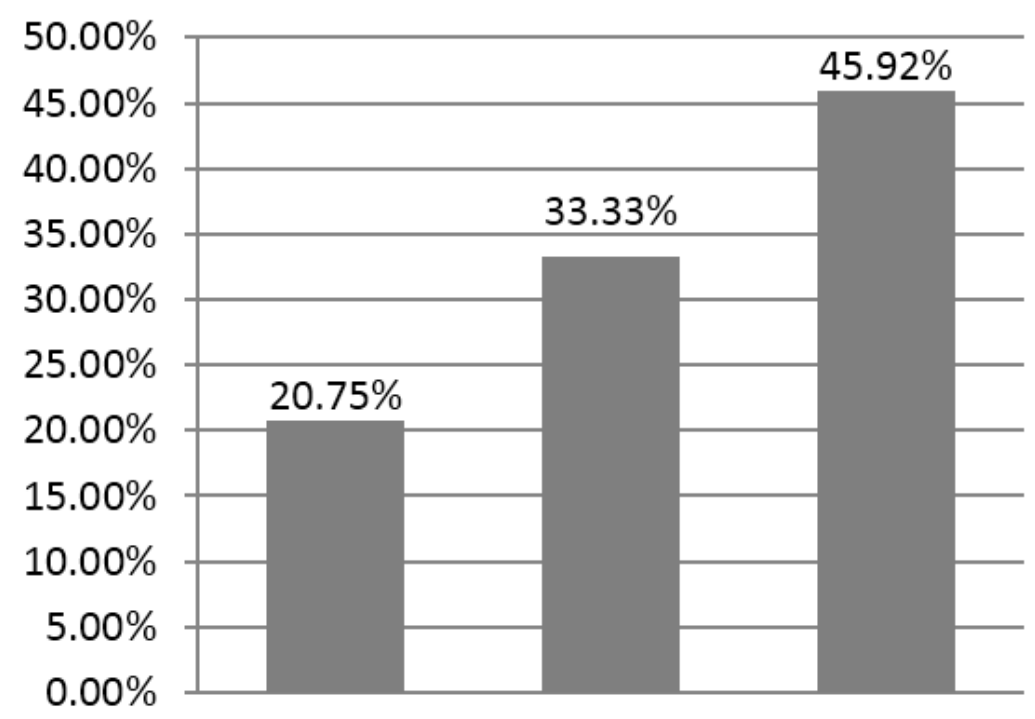

Gambar 2. Gaya Belajar Mahasiswa 
Hasil uji hipotesis menggunakan one way anova untuk mengetahui perbedaan antara jenis-jenis gaya belajar terhadap hasil belajar pemrograman visual 1 disajikan pada Tabel 1 .

Tabel 1. Hasil uji hipotesis

\begin{tabular}{cccc}
\hline & df & F & Sig. \\
\hline Between Groups & 2 & 2.698 & .071 \\
Within Groups & 156 & & \\
Total & 158 & & \\
\hline
\end{tabular}

Hasil uji one way anova menunjukkan bahwa nilai $F_{h i t u n g}$ sebesar 2,698 maka nilai tersebut lebih kecil dibandingkan dengan nilai $F_{\text {tabel }}$ yaitu 3,05 (2,698 < 3,05) dan nilai signifikansi sebesar 0,071, nilai ini juga melebihi ketentuan signifikansi yang telah ditentukan yaitu 0,05 atau 5\% (0,071 > 0,05). Dengan demikian dapat disimpulkan bahwa tidak terdapat perbedaan hasil belajar Pemrograman visual 1 mahasiswa Program Studi Pendidikan Teknologi Informasi dan Komputer IKIP PGRI Pontianak ditinjau dari gaya belajar. Dari uji anova di atas menunjukkan bahwa tidak ada perbedaan yang singnifikan antara jenis-jenis gaya belajar terhadaphasil belajar pemrograman visual 1 maka tidakperlu diadakan uji lanjut. Hal ini sejalan dengan penelitian yang dilakukan oleh Amin \& Suardiman (2016), di mana berdasarkan analisis data tidak ada perbedaan prestasi belajar matematika antara siswa yang mempunyai gaya belajar auditorial, visual, dan kinestetik.

Berdasarkan hasil penelitian dapat dipaparkan dari keseluruhan jumlah mahasiswa dengan kecenderungannya masing-masing bahwa terdapat 33 mahasiswa dengan kecenderungan gaya belajar visual, 53 mahasiswa dengan kecenderungan gaya belajar auditori dan 73 mahasiswa dengan kecenderungan gaya belajar kinestetik. Rerata skor kecenderungan dari masing-masing jenis gaya belajar dari yang paling tinggi adalah gaya belajar kinestetik 54,71; gaya belajar auditori 52,68 dan gaya belajar visual 52,61. Dengan demikian dalam penelitian ini gaya belajar kinestetik memberikan kontribusi terbesar terhadap hasil belajar Pemrograman visual 1 mahasiswa selanjutnya adalah gaya belajar auditori dan yang paling rendah kontribusinya adalah gaya belajar visual.

Data di atas menunjukkan bahwa gaya belajar kinestetik mempunyai hasil rata-rata yang lebih tinggi dengan gaya belajar yang lain. Maka sesuai dengan penelitian ini yang berorientasi dengan hasil belajar Pemrograman visual 1 yang banyak praktiknya. Gaya belajar kinestetik 
mempunyai orientasi pada gerakan (activity) maupun praktik langsung. Hal ini sesuai dengan pendapat De Porter dan Hernacki (2012) dalam bukunya quantum learning kecenderungan gaya belajar kinestetik adalah berorientasi pada fisik dan banyak gerakan dan suka terhadap sesuatu yang dapat menyibukkan dirinya. Seorang mahasiswayang mempunyai kecenderungan gaya belajar kinestetik maka akan sesuai dengan pembelajaran model proyek. Sehingga tepat sekali jika mahasiswa yang mempunyai kecenderungan gaya belajar kinestetik akan lebih mudah belajar untuk mengerjakan tugas Pemrogaraman Komputer. Maka sesuai dengan penelitian ini bahwa mahasiswa yang mempunyai kecenderungan gaya belajar kinestetik mempunyai nilai rerata yang lebih tinggi dibanding dengan gaya belajar yang lain, meski dalam penelitian ini perbedaan antara jenis-jenis gaya belajar tidaklah signifikan.

\section{SIMPULAN}

Berdasarkan hasil penelitian dapat disimpulkan tidak terdapat perbedaan hasil belajar pemrograman visual 1 yang signifikan dari masing-masing jenis gaya belajar dengan nilai $F_{\text {hitung }}$ sebesar 2,698 dan $F_{\text {tabel }}$ sebesar 3,05 dan nilai signifikansi sebesar 0,071. Terdapat 33 mahasiswa dengan kecenderungan gaya belajar visual, 53 mahasiswa dengan kecenderungan gaya belajar auditori dan 73 mahasiswa dengan kecenderungan gaya belajar kinestetik. Rerata skor kecenderungan dari masing-masing jenis gaya belajar dari yang paling tinggi adalah gaya belajar kinestetik 54,71, gaya belajar auditori 52,68 dan gaya belajar visual 52,61.

\section{DAFTAR PUSTAKA}

Amin, A., \& Suardiman, S. (2016). Perbedaan prestasi belajar matematika siswa ditinjau dari gaya belajar dan model pembelajaran. Jurnal Prima Edukasia, 4(1), 12-19.

Deporter,B., \& Hernacki,M. (2012). Quantum learning. Bandung: Kaifa

Gilakjani, A.P (2012). Visual, auditory, kinaesthetic learning styles and the impacts in english languge teaching. Journal of Studies in Education, 2(1), 104-113.

Law, Sue \& Glover, D. (2000). Educational leadership and learning practice, policy,and research. Philadelphia: Open University Press Buckingham.

Marcelino, M. (2004). Using a computer-based interactive system for the development of basic algorithmic and programming skills. International Conference on Computer Systems and Technologies. CompSysTech, 21, 171-187. 
Purwanto, N. (2007). Psikologi pendidikan. Bandung: Remaja Rosda karya.

Winkel, W.S. (2004). Psikologi pengajaran. Jakarta: Media Abadi. 